\title{
PERSONALITY TRAITS OF PATIENTS SUFFERING FROM PFO AND ASD AND INFLUENCE OF COVID-19 PANDEMIC TIME FOR PATIENTS SUFFERING FROM CONGENITAL HEART DEFECTS
}

DOI: $10.36740 /$ WLek202009206

\author{
Adrianna Skoczek, Paweł Prochownik, Natalia Podolec, Urszula Gancarczyk, Piotr Podolec, Monika Komar \\ CLINICAL DEPARTMENT OF CARDIAC AND VASCULAR DISEASES WITH THE INTENSIVE CARDIAC SUPERVISION SUBDIVISION, INSTITUTE OF CARDIOLOGY, \\ COLLEGIUM MEDICUM OF THE JAGIELLONIAN UNIVERSITY IN CRACOW, JOHN PAUL II HOSPITAL, CRACOW, POLAND
}

\begin{abstract}
Introduction: The work presents a research project carried out in John Paul II Hospital in Cracow in Clinical Department of Cardiac and Vascular Diseases with the Intensive Cardiac Supervision Subdivision, with participation of $100(50 \mathrm{~F}, 50 \mathrm{M})$ patients with congenital heart defects. The purpose of the work is to resolve the issue of personality specifics, and thus the different characteristics of people who suffer from congenital heart defects. Therefore, the following questions should be answered: Is there a relationship between personality traits and the occurrence of a congenital heart defect? What personality traits are characteristic for patients with congenital heart defects? The aim: We aimed to assess personality traits of clients suffering from PFO and ASD. The article also talks about how coronavirus pandemic affects patients with congenital heart disease

Materials and methods: The research was conducted by psychologist Adrianna Skoczek. We performed a psychological clinical assessment and conducted the psychological tests like Eysenck Personality Questionnaire-Revised Short Version [EPQ-R(S)] and Eysenck's Impulsivity Inventory [IVE] by Hans J. Eysenck and Sybil G. Eysenck, the State-Trait Anxiety Inventory [STAI] by C. D. Spielberger, R. L. Gorsuch, R. E. Lushene describing personality traits of patients. Patients ( $F=50, M=50)$, with ASD ( $n=70)$ and with PF0 ( $n=30)$. Results: In people suffering from ASD, the level of declared empathy was statistically significantly higher than the levels of impulsiveness and tendency to risk-taking. In people suffering from PF0, a statistically significant difference was observed only between the level of psychoticism and other variables. The level of declared empathy was statistically significantly higher than the levels of impulsiveness and tendency to risk-taking, a statistically significant difference was found between the analyzed variables - anxiety as a trait and anxiety as a condition.

Conclusions: The results of the study allowed us to isolate the specific personality traits of patients suffering from congenital heart defects.
\end{abstract}

KEY WORDS: atrial septal defect; patent foramen ovale; personality traits; congenital heart defects, COVID-19

Wiad Lek. 2020;73(9 p. II):1926-1933

\section{INTRODUCTION}

PFO - patent foramen ovale - a persistent oval hole is a remnant of an oval hole located in the atrial septum. Blood circulation in utero takes place through: the umbilical vein, the venous line to the inferior vena cava, then the blood is led to the right atrium where, joining the blood from the superior vena cava, through the oval opening it leads to the left atrium of the fetus [1].

After delivery, due to the increase in pressure in the left atrium, the primary septum adheres to the secondary septum, which leads to narrowing of the oval opening channel, and then in most cases to close the opening. In about $25 \%$ of cases, the primary and secondary septa do not completely merge, which leads to the formation of a permanent oval hole [1].

ASD - atrial septal defect - a defect in the atrial septum causes blood leakage between the atria. ASD losses are divided into: ASDII - secondary hole type - occurs by approx. $80 \%$ of subjects - incorrectly developed secondary septum, ASDI - primary hole type - occurs in approx. $15 \%$ of subjects - pathological development and connection of endocardial cushions, svSD - main vein type - occurs in approx. $5 \%$ of patients - complete or partial septal defect is found between the main vein and right pulmonary veins, csASD - coronary sinus type - occurs in approx. $1 \%$ of patients - complete or partial hypoplasia of the coronary sinus wall adjacent to the left atrium [1].

\section{THE AIM}

To show personality traits typical of patients with congenital heart defects.

The following research hypotheses were adopted:

1. Extraversion is characteristic of people suffering from congenital heart disease PFO.

2. Psychoticism is not characteristic of people with ASD congenital heart disease.

3. Neuroticism is clearly the strongest characteristic of people with congenital heart disease PFO.

4. Impulsiveness is characteristic of people with ASD congenital heart disease. 


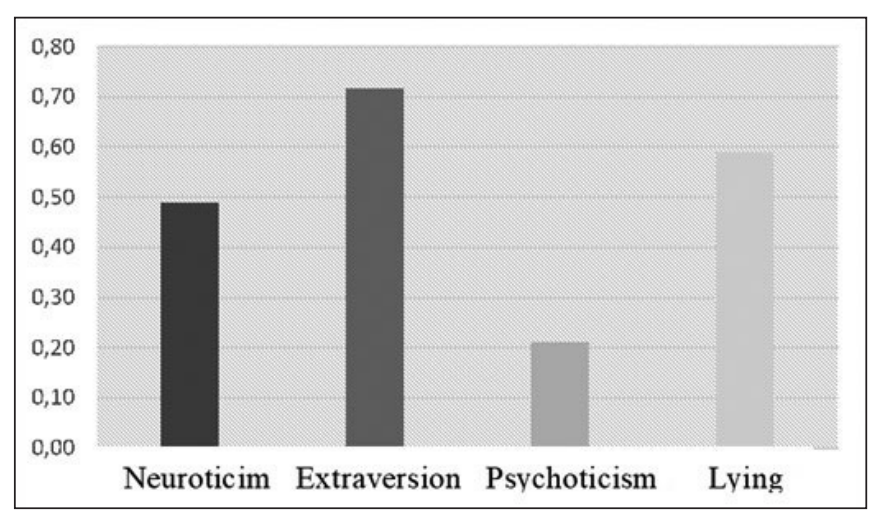

Fig. 1. The mean of the analyzed dimensions of the EPQ-R (S) tool Hans J. Eysenck and Sybil G. Eysenck for subjects with ASD defect

$E P Q-R(S)$, Eysenck Personality Questionnaire-Revised Short Version, ASD, atrial septal defect

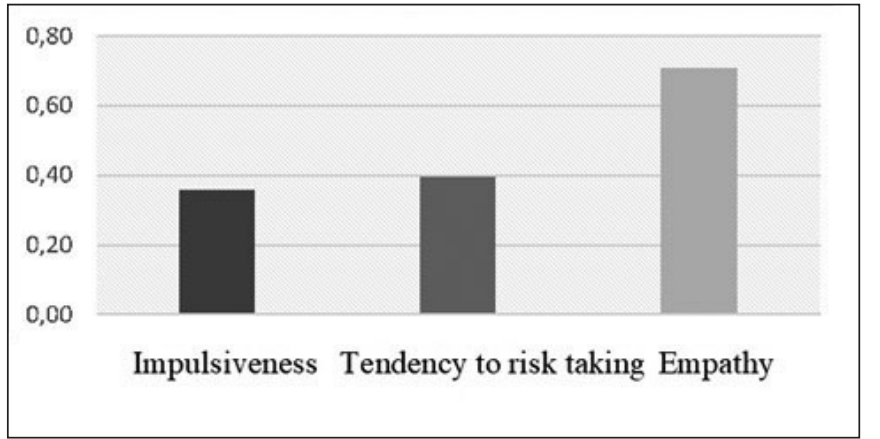

Fig. 2. Average of analyzed dimensions of IVE tool Hans J. Eysenck and Sybil G. Eysenck for subjects with ASD defect

IVE, Eysenck's Impulsivity Inventory, ASD, atrial septal defect

5. Tendency to risk-taking is not characteristic of patients suffering from ASD congenital heart disease.

6. Empathy is characteristic of people with PFO congenital heart disease.

7. Anxiety as a condition is characteristic of people suffering from ASD.

8. Anxiety as a trait is characteristic of people suffering from PFO.

\section{MATERIAL AND METHODS}

\section{INFLUENCE OF COVID-19 PANDEMIC TIME FOR PATIENTS SUFFERING FROM CONGENITAL HEART DEFECTS}

Each of the crises is associated with a negative impact on human mental health. Both patients who experienced various symptoms such as e.g. anxiety before the outbreak of the COVID-19 pandemic, and healthy people may deteriorate mental functioning [2].

The most important factors that affect the deterioration of a person's mental state during a pandemic are: isolation, lack of contact with loved ones, increasing domestic violence as well as a constant feeling of uncertainty about the future. In most countries, there are signs of depression as well as anxiety in

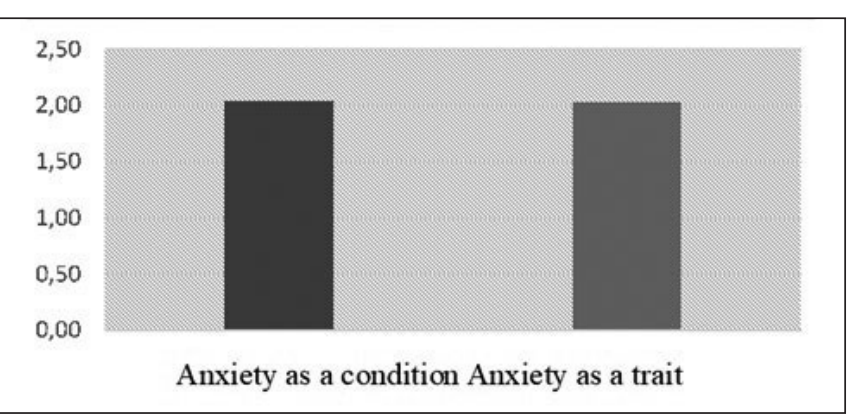

Fig. 3. Average of the analyzed dimensions of the STAI tool C. D. Spielberger, R. L. Gorsuch, R. E. Lushene for subjects with ASD defect

STAI, the State-Trait Anxiety Inventory, ASD, atrial septal defect

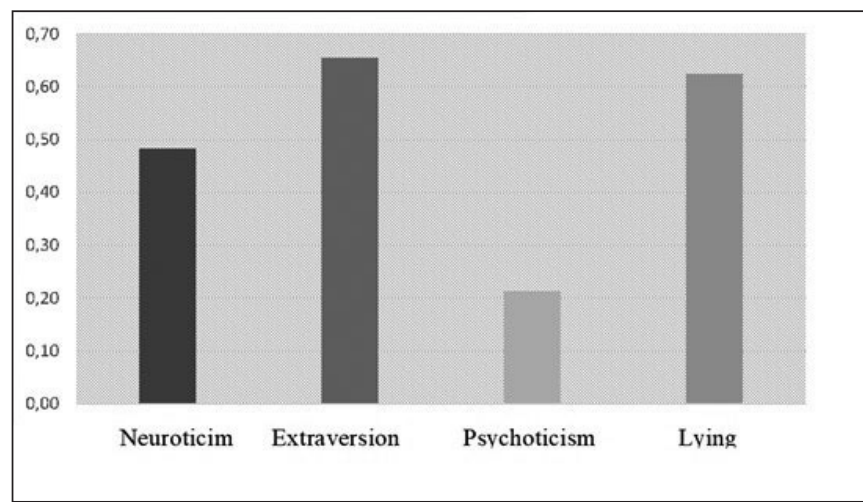

Fig. 4. Average of the dimensions of the $E P Q-R(S)$ tool Hans J. Eysenck and Sybil G. Eysenck for subjects with a PF0 defect.

EPQ-R(S), Eysenck Personality Questionnaire-Revised Short Version, PFO, patent foramen ovale

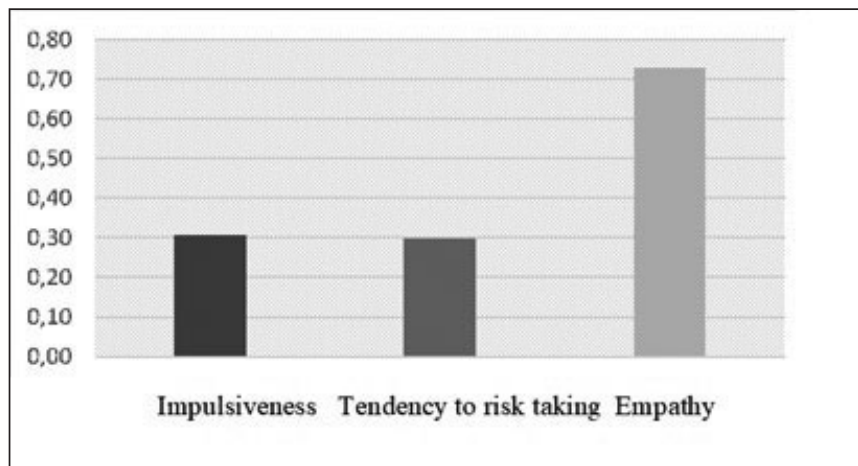

Fig. 5. Average of analyzed dimensions of IVE tool Hans J. Eysenck and Sybil G. Eysenck for subjects with PFO defect.

IVE, Eysenck's Impulsivity Inventory, PFO, patent foramen ovale

people healthy so far. The current pandemic situation directs people to reach for stimulants to reduce stress levels [2].

Research has been developed describing the level of extraversion associated with the current situation we are struggling with - COVID-19. People with a high level of extraversion were forced to increase social distance, which is very difficult for them. Higher conscientiousness results are associated with a lower tendency to violate recommendations [3].

People with cardiovascular disease (in particular, hypertension and coronary artery disease) have been shown to be at greater risk of COVID-19 infection. This 


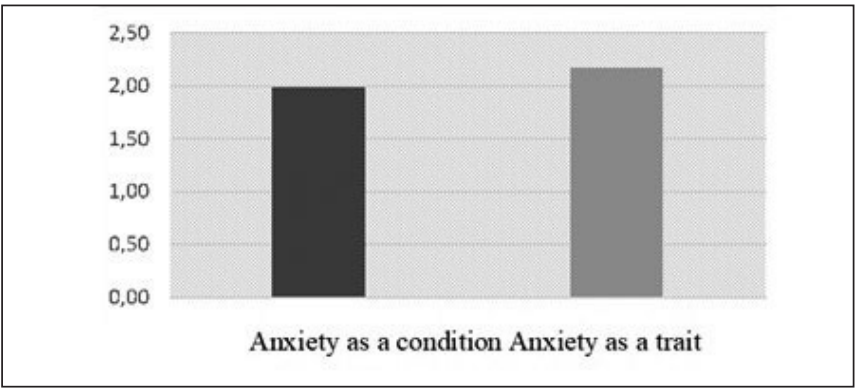

Fig. 6. The average of the analyzed dimensions of the STAI tool C. D. Spielberger, R. L. Gorsuch, R. E. Lushene for subjects with a PFO defect. STAI, the State-Trait Anxiety Inventory; PF0, patent foramen ovale

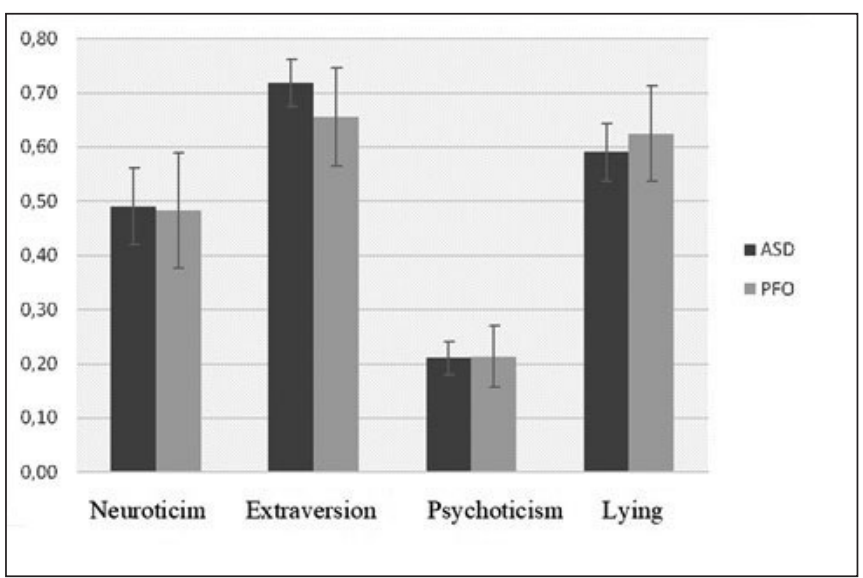

Fig. 7. Average levels of personality traits measured with the EPQ-R (S) tool Hans J. Eysenck and Sybil G. Eysenck, broken down by patients with ASD and PFO defects.

EPQ-R(S), Eysenck Personality Questionnaire-Revised Short Version, ASD, atrial septal defect; PF0, patent foramen ovale

has often been associated with accelerated patient death. Unfortunately, to date, no studies have been developed regarding the exposure of people suffering from congenital heart defects [4].

Thus we still do not know how COVID -19 affects people with congenital heart defects, not only physically but also mentally. It is therefore important to research the effects of SARS-CoV-2 on patients with congenital heart defects. Other studies, in turn, showed that during a pandemic people show a lot of psychological conflicts between the desire to adhere to some rules in order to live in safety and the desire to maintain normality [5].

Recently, care for all patients, including cardiologic patients, has been significantly more difficult due to the coronavirus pandemic. Many patients with both ASD and PFO may feel disturbed by the lack of systematic contact with their attending physician, especially since the ailments caused by SARS-CoV-2 infection may resemble the already known cardiological ailments. The patient is not able to determine on his own what disease he can attribute to it, whether he has a heart defect or perhaps a coronavirus infection. COVID-19 is a disease caused by infection with the SARS-CoV-2 virus, involving the rapid spread of inflammatory processes in various organs. It attacks lungs as well as the cardiovascular system. It may have a different course in different patients. Approximately $20 \%$ of

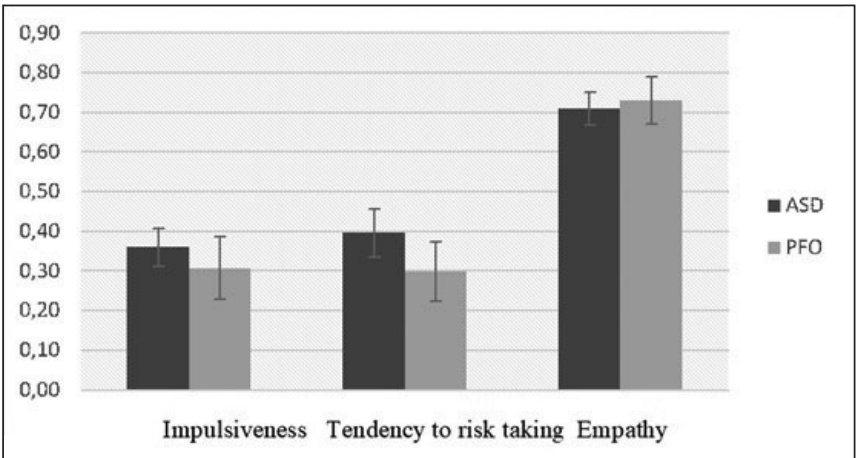

Fig. 8. Average levels of personality traits measured with the IVE tool Hans J. Eysenck and Sybil G. Eysenck, broken down by patients with ASD and PFO defects.

IVE, Eysenck's Impulsivity Inventory, ASD, atrial septal defect; PF0, patent foramen ovale

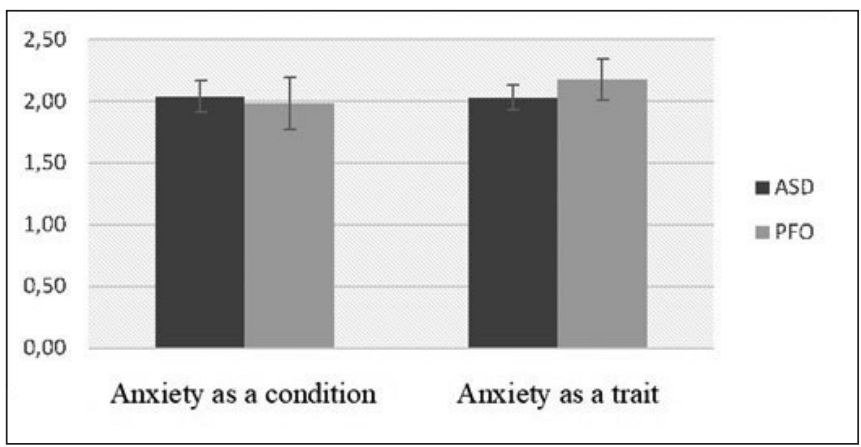

Fig. 9. Average levels of personality traits measured with the STAI tool $C$. D. Spielberger, R. L. Gorsuch, R. E. Lushene, broken down by patients with ASD and PFO defects.

STAl, the State-Trait Anxiety Inventory, ASD, atrial septal defect; PF0, patent foramen ovale

patients may have a severe course and these patients require hospitalization, intensive care and mechanical ventilation. About 1/5 -1/3 of hospital-treated patients have their cardiovascular system damaged, and about $40 \%$ of them die [6].

The site of entry of the SARS-CoV-2 virus is ACE 2 receptors that are found in the lungs, heart and kidneys. This virus then enters the endothelial cells, leading to their destruction. Damaged cells in the cardiovascular system initially cause microcirculation disorders, leading to vasoconstriction, which results in ischemia of many organs, intensification of inflammatory processes and hypercoagulability [6].

Common complications of SARS-CoV-2 infection are thrombophlebitis, acute coronary syndromes, myocarditis, acute heart failure as well as arrhythmias. Both arrhythmias and shortness of breath, chest pain, weakness, intolerance to physical exertion and swelling of the lower extremities can occur in PFO and ASD, as well as affect patients with these congenital heart defects and additionally infected with coronavirus. It should also be noted that drugs used to treat COVID-19 and complications such as antiviral drugs, chloroquine, hydroxychloroquine, azithromycin, antiarrhythmic and anticoagulant drugs also have proarrhythmic effects. In a study conducted in Wuhan, arrhythmias were seen in approximately $17 \%$ of 
Table 1. The severity of personality traits measured with the EPQ-R $(S)$ tool Hans J. Eysenck and Sybil G. Eysenck among those with ASD

\begin{tabular}{ccccccccccc}
\hline \multicolumn{2}{c}{ Neuroticism } & \multicolumn{2}{c}{ Extraversion } & \multicolumn{2}{c}{ Psychoticism } & \multicolumn{2}{c}{ Lying } & F & P \\
\hline M & SD & $\mathbf{M}$ & SD & $\mathbf{M}$ & SD & $\mathbf{M}$ & SD & \\
\hline 0,49 & 0,30 & 0,72 & 0,19 & 0,21 & 0,13 & 0,59 & 0,22 & 61,28 & $<0,001$ \\
\hline
\end{tabular}

M -mediana; SD - standard deviation; $F$ - result of variance analysis; $p$ - statistical significance

EPQ-R(S), Eysenck Personality Questionnaire-Revised Short Version, ASD, atrial septal defect

Table 2. The severity of personality traits measured by the IVE tool among subjects with ASD defect

\begin{tabular}{|c|c|c|c|c|c|c|c|}
\hline \multicolumn{2}{|c|}{ Impulsiveness } & \multicolumn{2}{|c|}{ Tendency to risk-taking } & \multicolumn{2}{|c|}{ Empathy } & \multirow{2}{*}{$\mathbf{F}$} & \multirow{2}{*}{$\mathbf{p}$} \\
\hline M & SD & M & SD & M & SD & & \\
\hline 0,36 & 0,20 & 0,40 & 0,26 & 0,71 & 0,17 & 58,97 & $<0,001$ \\
\hline
\end{tabular}

M -mediana; SD - standard deviation; $F$ - result of variance analysis; $p$ - statistical significance

IVE - Eysenck's Impulsivity Inventory, ASD - atrial septal defect

Table 3. Intensification of features measured with the STAI tool C. D. Spielberger, R. L. Gorsuch, R. E. Lushene among subjects with ASD defect

\begin{tabular}{cccccccccc}
\hline \multicolumn{2}{c}{ Anxiety as a condition } & \multicolumn{2}{c}{ Anxiety as a trait } & \multicolumn{3}{c}{$\mathbf{9 5 \%}$ Cl } \\
\hline $\mathbf{M}$ & SD & $\mathbf{M}$ & SD & $\mathbf{t}$ & $\mathbf{p}$ & $\mathbf{L L}$ & $\mathbf{U L}$ & $\mathbf{d}$ Cohena \\
\hline 2,03 & 0,43 & 2,04 & 0,54 & 0,12 & 0,904 & $-0,11$ & 0,13 & 0,02 \\
\hline
\end{tabular}

M - mediana; SD - standard deviation; $\mathrm{t}$ - Student's t test result; $\mathrm{p}$ - significance; $95 \% \mathrm{Cl}$ - confidence interval for the difference between means; $\mathrm{LL}$ and UL - lower and upper limits of the confidence interval

STAI - the State-Trait Anxiety Inventory; ASD - atrial septal defect

Table 4. The severity of personality traits measured with the EPQ-R (S) tool Hans J. Eysenck and Sybil G. Eysenck among the subjects with PF0 defect

\begin{tabular}{cccccccccc}
\hline \multicolumn{2}{c}{ Neuroticism } & \multicolumn{2}{c}{ Extraversion } & \multicolumn{2}{c}{ Psychoticism } & \multicolumn{2}{c}{ Lying } & F & P \\
\hline $\mathbf{M}$ & SD & $\mathbf{M}$ & SD & $\mathbf{M}$ & SD & $\mathbf{M}$ & SD & \\
\hline 0,48 & 0,30 & 0,66 & 0,25 & 0,21 & 0,16 & 0,63 & 0,25 & 17,47 & $<0,001$ \\
\hline
\end{tabular}

M - mediana; SD - standard deviation; $F$ - result of variance analysis; $\mathrm{p}$ - statistical significance

EPQ-R(S), Eysenck Personality Questionnaire-Revised Short Version, PF0, patent foramen ovale

Table 5. The severity of personality traits measured with the IVE tool Hans J. Eysenck and Sybil G. Eysenck among the subjects with PFO defect

\begin{tabular}{cccccccc}
\hline \multicolumn{2}{c}{ Impulsiveness } & \multicolumn{2}{c}{ Tendency to risk-taking } & \multicolumn{2}{c}{ Empathy } & F & P \\
\cline { 1 - 5 } M & SD & $\mathbf{M}$ & SD & M & SD & 44,41 & $<0,001$ \\
\hline 0,31 & 0,22 & 0,30 & 0,21 & 0,73 & 0,17 & 4
\end{tabular}

M -mediana; SD - standard deviation; $F$ - result of variance analysis; $p$ - statistical significance

IVE, Eysenck's Impulsivity Inventory; PF0, patent foramen ovale

Table 6. The severity of features measured with the STAI tool among those with a PFO defect

\begin{tabular}{cccccccccc}
\hline \multicolumn{2}{c}{ Anxiety as a condition } & \multicolumn{2}{c}{ Anxiety as a trait } & \multicolumn{3}{c}{$\mathbf{9 5 \%} \mathbf{C l}$} \\
\hline $\mathbf{M}$ & SD & $\mathbf{M}$ & SD & $\mathbf{t}$ & $\mathbf{p}$ & $\mathbf{L L}$ & $\mathbf{U L}$ & $\mathbf{d ~ C o h e n a}$ \\
\hline 2,17 & 0,47 & 1,99 & 0,59 & $-2,44$ & 0,021 & $-0,35$ & $-0,03$ & 0,34 & \\
\hline
\end{tabular}

$\mathrm{N}$ - number of observations; $\mathrm{M}$ - mediana; SD - standard deviation; $\mathrm{t}$ - Student's t test result; $\mathrm{p}$ - significance;

$95 \% \mathrm{Cl}$ - confidence interval for the difference between means; $\mathrm{LL}$ and $\mathrm{UL}$ - lower and upper limits of the confidence interval

STAI - the State-Trait Anxiety Inventory, PFO - patent foramen ovale

patients in intensive care. This study did not analyze the type of arrhythmias. It should be noted that the factors predisposing to a more severe course of COVID-19 are male sex, advanced age, hypertension, diabetes, obesity, and cardiovascular diseases. Knowledge about the mechanisms causing a worse course COVID-19 in patients with cardiovascular disease is under investigation. Nevertheless, these patients require special care due to the limited access to healthcare services and medical procedures. The patients themselves also often seek help too late because of the pre-infection medicine. In studies conducted in Hong Kong during the SARS-2 epidemic, it was noted that from the time of onset of angina pain to the initiation of invasive treatment - primary percutaneous coronary angioplasty, PCI was about 3.5 times longer than the corresponding period of the previous year [6]. 
Table 7. The relationship between anxiety and personality traits measured with the STAl tool by C. D. Spielberger, R. L. Gorsuch, R. E. Lushene and IVE tool Hans J. Eysenck and Sybil G. Eysenck

\begin{tabular}{cccc}
\hline \multirow{2}{*}{ Impulsiveness } & & Anxiety as a condition & Anxiety as a trait \\
\hline \multirow{2}{*}{ Tendency of risk taking } & Pearson $r$ & 0,21 & 0,36 \\
\cline { 2 - 4 } & Revelance & 0,040 & $<0,001$ \\
\cline { 2 - 4 } Empathy & Pearson $r$ & $-0,30$ & 0,003 \\
\hline & Revelance & $<0,38$ & 0,27 \\
\cline { 2 - 4 } & Pearson $r$ & 0,22 & 0,007 \\
\hline
\end{tabular}

STAI - the State-Trait Anxiety Inventory;

IVE - Eysenck's Impulsivity Inventory;

Table 8. The relationship between anxiety and personality traits measured with the STAI tool by C. D. Spielberger, R. L. Gorsuch, R. E. Lushene and EPQ-R (S) Hans J. Eysenck and Sybil G. Eysenck

\begin{tabular}{cccc}
\hline & & Anxiety as a condition & Anxiety as a trait \\
\hline \multirow{2}{*}{ Neuroticism } & Pearson $r$ & 0,40 & 0,51 \\
\cline { 2 - 4 } & Revelance & $<0,001$ & $<0,001$ \\
\cline { 2 - 4 } Extraversion & Pearson $r$ & $-0,22$ & 0,027 \\
\cline { 2 - 4 } Psychoticism & Revelance & 0,15 & 0,16 \\
\cline { 2 - 4 } & Pearson $r$ & 0,11 & 0,115 \\
\cline { 2 - 4 } & Revelance & 0,275 & $-0,16$ \\
\cline { 2 - 4 } & Pearson $r$ & $-0,08$ & 0,123 \\
\hline
\end{tabular}

EPQ-R(S) - Eysenck Personality Questionnaire-Revised Short Version

STAI - the State-Trait Anxiety Inventory;

Table 9. Relationship of personality traits measured with IVE tools Hans J. Eysenck and Sybil G. Eysenck and EPQ-R (S) Hans J. Eysenck and Sybil G. Eysenck

\begin{tabular}{ccccc}
\hline \multirow{2}{*}{ Neuroticim } & & Impulsiveness & Tendency to risk-taking & Empathy \\
& Pearson $r$ & 0,53 & $-0,23$ & 0,39 \\
\cline { 2 - 5 } & Revelance & $<0,001$ & 0,019 & 0,001 \\
\hline \multirow{2}{*}{ Extraversion } & Pearson $r$ & 0,09 & 0,19 & 0,06 \\
\cline { 2 - 5 } & Revelance & 0,362 & 0,056 & $-0,16$ \\
\hline \multirow{2}{*}{ Psychoticism } & Pearson $r$ & 0,27 & 0,06 & 0,121 \\
\cline { 2 - 5 } & Revelance & 0,006 & 0,526 & 0,00 \\
\cline { 2 - 5 } & Pearson $r$ & $-0,36$ & $-0,37$ & 0,968 \\
\hline
\end{tabular}

EPQ-R(S) - Eysenck Personality Questionnaire-Revised Short Version

IVE - Eysenck's Impulsivity Inventory;

Therefore, on April 21, 2020, European Society of Cardiology (ESC Guidance for the Diagnosis and Management of CV Disease during the COVID-19 Pandemic) guidelines have been published which aim to provide appropriate care to this group of patients. Also other societies around the world such as the Canadian Association of Interventional Cardiology, American College of Cardiology's (ACC), Interventional Council and Society of Cardiovascular Angiography and Intervention (SCAI), Society for Cardiovascular Angiography and Interventions Emerging Leader Mentorship (SCAI ELM) Members and Graduates, Peking
Union Medical College Hospital have developed guidelines for the management of patients with STEMI and NSTEMI myocardial infarction depending on the coexistence of COVID-19 [6].

According to the aforementioned guidelines, patients requiring further diagnosis or invasive treatment were divided into groups defining the need for urgent or postponed medical procedures. For example, in patients with ASD or PFO, closure of the defect in the atrial septum, obstruction of the oval opening should be performed in the planned mode, i.e. it can be postponed for at least 3 months [6]. 


\section{STATISTICAL DEVELOPMENT OF RESEARCH RESULTS}

Statistical tests were performed using IBM SPSS Statistics version 25 to test the hypotheses set out in the study. With its help, frequency analysis, analysis of basic descriptive statistics together with the Kolmogorov-Smirnov distribution normality test, Pearson $r$ correlation analysis, variance analysis in intra-group schemas, Mann-Whitney U tests for independent samples and Student's t tests for dependent and independent samples were performed.

\section{CONGENITAL HEART DISEASE ASD AND PERSONALITY TRAITS OF PEOPLE SUFFERING FROM IT}

In order to verify the next hypothesis, analogous analyzes of personality traits were carried out among subjects with ASD congenital heart disease. First, an analysis of the variance of results obtained by this group of subjects on the scales of the EPQ-R (S) tool [7]. Due to violation of the assumption about the sphericity of variables, the Greenhouse-Geisser correction was applied in reporting the result of the analysis. The test result turned out to be statistically significant $-\mathrm{F}(2.20 ; 151.53)=61.28$; $\mathrm{p}<0.001 ; \eta 2=0.47$. The eta value of the square indicates that the observed effect is strong. In order to check the essence of this effect, a post hoc analysis (with Bonferroni correction) was carried out. The only insignificant difference in the analyzed case is that between levels of neuroticism and the scale of lying. The averages described are presented in Table 1 and Figure 1.

Then, an analogous analysis of the variance of results obtained on the IVE scales was carried out [8]. Due to violation of the assumption about the sphericity of variables, the Greenhouse-Geisser correction was applied in reporting the result of the analysis. The test result turned out to be statistically significant $-\mathrm{F}(1.68 ; 115.68)=58.97 ; \mathrm{p}<0.001 ; \eta 2=0.46$. The eta value of the square indicates that the observed effect is very strong. In order to check the essence of this effect, a post hoc analysis (with Bonferroni correction) was carried out. The level of declared empathy was statistically significantly higher than the levels of impulsiveness and tendency to risk-taking. The difference between impulsiveness and tendency to risk-taking turned out to be statistically insignificant. The values of the discussed averages and the result of the analysis of variance are presented in Table 2 and Figure 2 .

Then the Student's t-test analysis for repeated measurements was performed. The results obtained by the subjects with ASD defect were compared on the scales of the STAI tool [9].

Based on the results presented in Table 3, no statistically significant differences were found between the analyzed variables. The compared means are illustrated in Figure 3.

\section{CONGENITAL HEART DISEASE PFO AND PERSONALITY TRAITS OF PEOPLE SUFFERING FROM IT}

In order to verify the next hypothesis, analogous analyzes were carried out, but among those with a PFO defect. First, an analysis of the variance of results obtained by this group of subjects on the scales of the EPQ-R (S) tool was carried out [7]. The test result proved to be statistically significant - $\mathrm{F}(3 ; 87)=17.47 ; \mathrm{p}<0.001 ; \eta 2=0.38$. The eta value of the square indicates that the observed effect is strong. In order to check the essence of this effect, a post hoc analysis (with Bonferroni correction) was carried out. A statistically significant difference was observed only between the level of psychoticism and other variables. The discussed averages are presented in Table 4 and Figure 4.

Then, an analogous analysis of the variance of results obtained on the IVE scales was carried out [8]. The test result turned out to be statistically significant - F $(2,58)$ $=44.41 ; \mathrm{p}<0.001 ; \eta 2=0.61$. The eta value of the square indicates that the effect observed is very strong. In order to check the essence of this effect, a post hoc analysis (with Bonferroni correction) was carried out. The level of declared empathy was statistically significantly higher than the levels of impulsiveness and tendency to risk-taking. The difference between impulsiveness and tendency to risk-taking turned out to be statistically insignificant. The values of the discussed means and the result of the analysis of variance are presented in Table 5 and Figure 5.

Then the Student's t-test analysis for repeated measurements was performed. The results obtained by the subjects with PFO defect were compared on the scales of the STAI tool [9].

Based on the results presented in Table 6, a statistically significant difference was found between the analyzed variables. The compared means are illustrated in Figure 6.

\section{INFLUENCE OF THE TYPE OF HEART DEFECT ON PERSONALITY TRAITS}

To verify the next hypothesis, a series of Mann-Whitney U tests were conducted. A nonparametric test was used due to a clear violation of the assumption about the equivalence of the compared groups. First, the influence of the type of heart defect on personality traits measured with the tool EPQ-R (S) [7]. The test result turned out to be statistically insignificant in the case of neuroticism $(\mathrm{p}=0.940)$, extraversion $(\mathrm{p}=0.349)$, psychoticism $(\mathrm{p}=0.917)$ and the scale of lying $(\mathrm{p}=0.348)$. The compared means are illustrated in Figure 7.

Then Mann-Whitney $U$ tests were carried out for independent samples comparing the levels of severity of traits measured with the STAI tool [9] in the group with ASD and PFO defects. The test result was insignificant in the case of differences in the levels of impulsiveness $(\mathrm{p}=0.190)$, tendency to risk-taking $(\mathrm{p}=0.104)$ and empathy $(\mathrm{p}=0.639)$. The compared means are illustrated in Figure 8 .

Then Mann-Whitney $U$ tests were carried out for independent samples comparing the levels of severity of traits measured with the STAI tool [4] in the group with ASD and PFO defects. The test result was insignificant in the case of the difference in levels of anxiety as both a condition $(\mathrm{p}=0.399)$ as well as as traits $(\mathrm{p}=0.194)$. The compared means are illustrated in Figure 9.

In addition, a series of Pearson $r$ correlations were made between the scales used in the study of tools. First, the 
results on the IVE scales were compared with [8] and STAI tool [9]. Based on the results presented in Table 1-6, statistically significant correlations were found between all variables. The results on the anxiety scale as a state correlate positively, weakly with the results on the impulsiveness and empathy scales. This means that as the results on the anxiety scale as a state increase, the results on the impulsiveness and empathy scales increase. A statistically significant, moderate but negative correlation with results on the tendency to risk-taking scale was found in the relationship between anxiety as a condition and tendency to risk-taking. This means that as results on the anxiety scale increase as a result, the results on the tendency to risk-taking scale decrease. In the case of results on the anxiety scale as a feature, statistically significant correlations were found with the results on all scales of the IVE tool [8]. In the case of the relationship with impulsiveness, it is positive and moderate, and empathy is positive, but weak. In the case of the relationship between the results on the anxiety scale as a feature and the results on the tendency to risk-taking scale, a statistically significant, moderate, but negative relationship was also observed (Table 7-9).

\section{ETHICAL STATEMENT}

The authors are accountable for all aspects of the work in ensuring that questions related to the accuracy or integrity of any part of the work are appropriately investigated and resolved. The study was approved by Bioethics Commission of Jagiellonian University in Cracow (No. 1072.6120.132.2017 from 28th September 2017) and informed consent was taken from all the patients. All patients agreed to the examination (part of the studies completed before the surgery, some after the surgery). Patients expressed willingness to participate in the operation, and the study submitted reported and approved by the bioethics committee. The study involved completing three psychological tests (EPQ-R(S), IVE, STAI) examining the personality structure and level of anxiety. This article does not contain any studies with human participants performed by any of the authors. This article does not contain any studies with animals performed by any of the authors. This article does not contain any studies with human participants or animals performed by any of the authors.

\section{DISCUSSION}

In people suffering from ASD, the only insignificant difference in the analyzed case is that between levels of neuroticism and the scale of lying. The level of declared empathy was statistically significantly higher than the levels of impulsiveness and tendency to risk-taking. The difference between impulsiveness and tendency to risk-taking turned out to be statistically insignificant. Based on the results, no statistically significant difference was found between the analyzed variables - anxiety as a trait and anxiety as a condition.
In people suffering from $\mathrm{PFO}$, a statistically significant difference was observed only between the level of psychoticism and other variables. The level of declared empathy was statistically significantly higher than the levels of impulsiveness and tendency to risk-taking. The difference between impulsiveness and tendency to risk-taking turned out to be statistically insignificant. Based on the results, a statistically significant difference was found between the analyzed variables - anxiety as a trait and anxiety as a condition.

\section{CONCLUSIONS}

The results of the study allowed us to isolate the specific personality traits of patients suffering from congenital heart defects.

\section{REFERENCES}

1. Plaskota K, Hoffman P. Patologie przegrody międzyprzedsionkowej - związek z udarem mózgu. Klinika Wad Wrodzonych Serca, Instytut Kardiologii im. Prymasa Tysiąclecia Stefana Kardynała Wyszyńskiego w Warszawie. Kardiol Dypl 2019;02 [download 12.10.2019r].

2. Policy Brief COVID-19 and the Need for Action on Mental Health, may 2020, United Nations

3. Carvalho LF, Pianowski G, Gonçalves AP. Personality differences and the COVID-19: Are extroversion and conscientiousness personality traits associated with engagement in containment measures? Trends Psychiatry Psychother. 2020;42(2). [http://dx.doi.org/10.1590/22376089-2020-0029].

4. Tan W, Aboulhosn J. The cardiovascular burden of coronavirus disease 2019 (COVID-19) with a focus on congenital heart disease. Inter J Cardiol 2020;309:70-77

5. Bacon AM, Corr PJ Brief report Coronavirus (COVID-19) in the United Kingdom: A personality-based perspective on concerns and intention to self-isolate. Br J Health Psychol 2020 Apr 29. doi: 10.1111/bjhp. 12423

6. Sokolski M, Sokolska JM, Ponikowski P, et al. Choroby układu sercowonaczyniowego w czasie pandemii COVID-19 w świetle aktualnych danych naukowych oraz stanowisk European Society of Cardiology i European Society of Hypertension. Med Prakt. 2020;5:12-44

7. Eysenck HJ, Eysenck SG, Jaworska A. EPQ-R. Kwestionariusze Osobowości Eysencka EPQ-R i EPQ-R w wersji skróconej, Polskie Normalizacje. Warszawa: Pracownia Testów Psychologicznych Polskiego Towarzystwa Psychologicznego, 2006.

8. EysenckHJ, Eysenck SG, Jaworska A. IVE. Impulsywności. Impulsywność, Skłonność do ryzyka, Empatia. Warszawa: Pracownia Testów Psychologicznych Polskiego Towarzystwa Psychologicznego, 2006.

9. Spielberger DC, Gorsuch RL, Lushene R, et al. STAI. Inwentarz Stanu i Cechy Lęku. Polska adaptacja STAI. Podręcznik, wydanie czwarte, rozszerzone. Warszawa: Pracownia Testów Psychologicznych Polskiego Towarzystwa Psychologicznego, 2011.

\section{ORCID and contributionship}

Adrianna Skoczek - 0000-0002-3952-9660 A-F

Pawet Prochownik - 0000-0002-6957-3590 B-F

Natalia Podolec - 0000-0003-0192-7310 B,F

Urszula Gancarczyk - 0000-0003-2283-3356 B,E,F

Piotr Podolec - 0000-0001-6101-2935 A,D-F

Monika Komar - 0000-0001-5341-2947 A-F 


\section{Acknowledgments}

We would like to thank everyone who contributed to this work, the Director of the Hospital, John Paul II Hospital, The Clinical Department of Cardiac and Vascular Diseases with the Intensive Cardiac Surgeon Division Institute of Cardiology, and Collegium Medicum of the Jagiellonian University in Cracow, heads of Departments, as well as the Bioethics Committee, and in particular patients who did not refuse the examination.

\section{Conflict of interest}

Authors declare no conflict of interest.

\section{CORRESPONDING AUTHOR}

Adrianna Skoczek

Baczków 210, Zakatek Street, 32-708 Baczków, Poland tel: +48 790706725

e-mail:adriannaskoczek@gmail.com

Reseived: 15.07 .2020

Accepted: 10.09 .2020 